\title{
STRATEGY TO IMPROVE THE CLASS OF AMBON ARCHIPELAGO FISHERIES PORT INTO AN OCEAN FISHERY PORT USING SWOT ANALYSIS
}

\author{
Ruth Phetrosina Soumokil \\ Faculty of Engineering, Pattimura University, Jl. Ir. M. Putuhena, Ambon, 97128, Indonesia \\ E-mail korespondensi: ut.soumokil@gmail.com
}

\begin{abstract}
ABSTRAK
Salah satu faktor penting dalam pengembangan usaha perikanan, khususnya kegiatan penangkapan ikan, adalah tersedianya infrastruktur dermaga atau tempat berlindung bagi kapal penangkap ikan dan pendaratan ikan hasil tangkapannya. Prasarana tersebut berupa Pelabuhan Perikanan atau Pangkalan Pendaratan Ikan sebagai tempat atau pangkalan kapal penangkap ikan. Penelitian ini bertujuan untuk mengkaji kondisi Pelabuhan Perikanan Nusantara (PPN) Ambon terhadap kriteria Pelabuhan Perikanan Samudera (PPS), dan merumuskan strategi pengembangan PPN Ambon dalam rangka meningkatkan kelasnya menjadi Pelabuhan Perikanan Samudera. Metode yang digunakan dalam penelitian ini adalah deskriptif. Teknik pengumpulan data dilakukan dengan penyebaran kuesioner, wawancara, dan pengumpulan data sekunder. Pengambilan sampel dilakukan dengan menggunakan purposive sampling sebanyak 20 responden kunci. Alat analisis yang digunakan adalah analisis deskriptif dan analisis SWOT. Hasil penelitian ini menunjukkan bahwa: Operasi yang ada di AFP Ambon menunjukkan perkembangan yang meningkat dari tahun ke tahun, baik dalam pendaratan ikan, kunjungan kapal nelayan, distribusi pasokan, penerimaan negara bukan pajak, serta jumlah nelayan dan tenaga kerja. Dari hasil penelitian Strategi Pembangunan AFP Ambon dalam rangka peningkatan kelas Pelabuhan Perikanan Laut, dihasilkan sepuluh strategi.
\end{abstract}

Kata Kunci: Pelabuhan Perikanan Nusantara; Kondisi Saat Ini; Analisis SWOT; Pelabuhan Perikanan Laut

\begin{abstract}
An essential factor for the development of fisheries business, especially fishing activities, is the availability of infrastructure for berths or shelter for fishing vessels and landing their catch fish. The infrastructure is in the form of a Fishing Port or Fish Landing Base as a place or base for fishing vessels. This research aimed to examine the condition of Archipelago Fisheries Port $(A F P)$ on the criteria of an Ocean Fishery Port (OFP), and formulated a strategy for developing Ambon AFP in order to increase its class to an Ocean Fishery Port. The method used in this research was descriptive. Data collection techniques carried out by distributing questionnaires, interviews, and secondary data collection. Sampling was done by using purposive sampling as many as 20 key respondents. The analytical tool used was descriptive analysis and SWOT analysis. The results of this study indicate that: Existing operations in Ambon AFP show increasing development from year to year, both in fish landing, fishing boat visits, supply distribution, non-tax state revenue, and the number of fishers and labour. From the Ambon AFP Development Strategy's research results in the context of improving the class of being an Ocean Fishery Port, ten strategies were produced.
\end{abstract}

Keywords : Archipelago Fisheries Port; Existing Condition;SWOT Analysis; Ocean Fishery Port 


\section{INTRODUCTION}

Ambon Archipelago Fisheries Port (Ambon AFP) is a fishing port that provides services to the fishing fleet, primarily to serve fishing vessels operating in Arafura Indonesia's Exclusive Economic Zone (EEZ), Banda sea waters and Seram sea. When viewed from the structure of the fishing fleet that visits and has activities in Ambon AFP so far, it is more dominated by largescale fishing vessels (industry) above $30 \mathrm{GT}$. Meanwhile, for small-scale fishing vessels under 30 GT (Kim \& Yeo, 2020), most activities in their fields or fishing centres which are in the bay of Ambon and on the coast of Ambon island. With its facilities, Ambon AFP has been supporting fishing activities in three potential Fisheries Management Areas namely WPP 714, WPP 715 and WPP 718 (Soemarmi \& Diamantina, 2019), ranging from the mooring, loading and unloading, logistical supply, fisheries guidance, distribution facilitation and marketing of fishery products to facilitate the growth of the fishing industry through the fishing industry area owned by Ambon AFP. The direct impact of increased production, an increased supply of fish for local consumption, increased exports, employment, and increased Non-tax Revenue and Locally-generated revenue. Indirect impacts growth of other economic activities both within the port and around the port. These include the growth of the real sector, such as the fish processing industry, kiosks, stalls/restaurants, and other services. In addition to the contribution and role of the Ambon AFP in supporting the utilization of Maluku fisheries resources and Ambon City, the support and attention of the central government to the development of the regional fisheries sector is also extensive. From various programs and activities including the proposal to establish Maluku as the National Fish Barn (Bahasoan et al., 2020), the Minapolitan Program and the Master Plan for the Acceleration and Expansion of Indonesia's Economic Development. The proposed designation of Maluku as a National Fish Barn is expected to increase the productivity of the capture fisheries and aquaculture business and trigger the fish processing industry's development. In this case, adequate infrastructure is needed, such as a fishing port. The government launched the Minapolitan Program; in this case, the Ministry of Maritime Affairs and Fisheries, in which Ambon was designated as one of the Minapolitan development areas (Raissa et al., 2014). The center of capture fisheries production and trade that can as the main driver of the economy in the Minapolitan area is a fishing port. In developing this minapolitan, Ambon AFP is designated as the core zone of the capture fisheries Minapolitan area in Ambon. Besides, the government has established the Maluku Islands in corridor six of the 2011-2025 Indonesian Economic Acceleration and Expansion Master Plan (Septiono et al., 2016) in which the master plan for processing the fisheries industry in Maluku be built-in Benjina, Tual, Ambon, and Seram. Furthermore, in the master plan, Ambon, as an economic centre, needs to be pursued downstream activities of the export-oriented fishing industry to create jobs through the creation of industrial value-added. In this case, the support of fishing ports becomes a vital role in the master plan. For some of the reasons above, the challenges faced by the Ambon AFP in carrying out their roles and functions in the future will be even more significant. Therefore, increasing the facility's capacity and increasing the class to become an Ocean Fishery Port (OFP) is necessary to play an optimal role in the development of Maluku fisheries. This research aimed to review the Ambon AFP condition against the criteria of an OFP and formulating a strategy for developing Ambon AFP in the context of upgrading its class to OFP.

\section{a. Definition of a Fishing Port}

Fishing Port is a place consisting of land and waters around it with certain boundaries as a place for government activities and fishery business system activities used as a place for fishing boats to dock, anchor and or load and unload fish equipped with shipping safety facilities and supporting fisheries activities (ministerial regulation number: PER.08 / MEN / 2012) (Kementerian Kelautan dan Perikanan, 2012).

\section{b. Carrying Capacity of Fishing Ports}

According to Syahril (2000), the pattern of operational activities at the Fishery Port or Fish Landing Base (PP/PPI) is divided into two activities, namely: operational activities in the 
Sea/River and operational activities on land. Operational activities on the Sea/River include the following cycle of activities: Fishing, Landing at the loading dock, Services at loading docks, Maintenance and repair, Berthing and berthing. Operational activities on land, include the following activities: Auction of catches, Sorting and packing, Processing, Transportation, Marketing.

\section{c. Classification of Fishing Ports}

In accordance with the regulation of the Minister of Marine Affairs and Fisheries of the Republic of Indonesia number: PER.08 / MEN / 2012 (Kementerian Kelautan dan Perikanan, 2012), fishing ports are classified into four classes on the basis of service weight and load, vessel operating range and market orientation as follows:

1. Ocean Fishing Port (Class A) with the following criteria: Able to serve fishing vessels carrying out fishing activities in Indonesian waters, ZEEI and the high seas, have mooring and anchoring facilities for fishing boats with a size of at least 60GT, The length of the wharf should be at least $300 \mathrm{~m}$, with a pool of at least minus $3 \mathrm{~m}$, able to accommodate fishing boats of at least 100 units or a total of at least 6000GT, Utilize and manage at least 20 Ha of land, Fish that are landed partly for export, There are loading and unloading activities of fish and marketing of fishery products an average of 50 tons per day and, There is a fish processing industry and other supporting industries.

2. Archipelago Fishery Port (Class B), with the following criteria: Able to serve fishing boats that carry out fishing activities in Indonesian waters and ZEEI, Has mooring and anchoring facilities for fishing boats measuring at least 30GT, The length of the pier should be at least $150 \mathrm{~m}$ with a pool depth of at least minus $3 \mathrm{~m}$, able to accommodate fishing boats of at least 75 units or a total of at least 2,250 GT, Utilize and manage at least $10 \mathrm{Ha}$ of land, There are loading and unloading activities of fish and marketing of fishery products an average of 30 tonnes per day and, There is a fish processing industry and other supporting industries.

3. Coastal Fishing Port (class C) with the following criteria : Able to serve fishing boats carrying out fishery activities in Indonesian waters, Has mooring and anchoring facilities for fishing boats measuring at least 10GT, The length of the pier should be at least $100 \mathrm{~m}$ with a pool depth of at least minus $2 \mathrm{~m}$, able to accommodate fishing boats of at least 30 units or a total of at least $300 \mathrm{GT}$, Utilize and manage at least $5 \mathrm{Ha}$ of land, There is an activity of loading and unloading fish and marketing of fishery products an average of 5 tons per day, There is a fish processing industry and other supporting industries.

4. Fish Landing (Class D) with the following criteria : Able to serve fishing boats carrying out fishery activities in Indonesian waters, Has mooring and anchoring facilities for fishing boats with a size of at least 5GT, The length of the pier should be at least $50 \mathrm{~m}$ with a pool depth of at least minus $1 \mathrm{~m}$, able to accommodate fishing boats of at least 15 units or a total of at least 75 GT, Utilize and manage at least 1 Ha of land, There are fish loading and unloading activities and marketing of fishery products at an average of 2 tons per day.

\section{d. Fishery Port Facilities}

\section{Main Facilities}

Main Facilities or also said to be infrastructure are basic facilities required for activities at a port. This facility serves to ensure the safety and smooth operation of the ship both while sailing in and out of the port and when docked at the port. These basic facilities include: a wharf, a harbor pool, a navigation aid, a breakwater or a breakwater.

\section{Functional Facilities}

An important functional facility that must be integrated with the fishing port area is the Fish Auction Place (TPI) which functions as a marketing place for fishery products using an auction system, while other facilities include processing facilities, drying, ice factories, cold storage, workshops, slipways (docking) and places to fill ship supplies do not have to be within the scope of the port area and the management system can be outside the port management. 


\section{Supporting Facilities}

Supporting facilities are facilities that indirectly increase the role of the port or the actors to gain comfort in carrying out activities at the port. Supporting facilities consist of welfare facilities (MCK, polyclinic, warung, prayer room) and administrative facilities (management office, harbormaster, customs).

\section{e. SWOT}

SWOT is a way to systematically identify various factors in order to formulate a company strategy. This analysis is based on logic to maximize strength (strengths) and opportunities (opportunities), but simultaneously can minimize weaknesses and threats. SWOT analysis considers internal environmental factors, strengths and weaknesses, as well as external environmental opportunities and threats facing the business world. SWOT analysis compares external factors, opportunities and threats, with internal factors, strengths and weaknesses, so that a company's strategic decisions can be taken from this analysis. SWOT analysis is preceded by identifying the position of the company or institution through evaluating the value of internal factors and evaluating the value of external factors.

\section{MATERIAL AND METHODS}

The Material used in this research is: (1) Main Facilities, Functional Facilities and Supporting Facilities which exist at Ambon AFP, (2) operational performances such us: catching results based on catching area, a fish distribution based on marketing areas, a fish distribution based on marketing areas, amount of fish landed for 2013 - 2017 and fish processing industry at Ambon AFP.

The method used in this research was descriptive survey method (Salaria, 2003). The descriptive method aims to solve existing problems in the presence of an object by collecting data, compiling, analyzing, explaining, and drawing conclusions.

\section{a. Research Location and Time}

This research took place in Ambon AFP for 2 months, namely December 2018 - January 2019.

\section{b. Data Types and Sources}

The type of data used in this study consisted of primary data and secondary data. Primary data was collected at surveys and measurements directly in the field. The survey was conducted by conducting a structured interview (questionnaire) of several respondents, consisting of several stakeholders and authority holders related to the Ambon AFP. Secondary data was needed to support the evaluation of Ocean Fishery Port criteria, obtained from local government agencies and other relevant agencies. The collected data was then identified and classified according to type, then presented in tables, figures, and graphs.

\section{c. Research Variables}

The components that will be measured and assessed in this study, include : (1) Aspect of OFP Criteria, including Fishing area for the past 5 years, Mooring facilities, Pier length and pond depth, Capacity for fishing vessels over the past 5 years, The number of fish landed during the last 5 years, Land area, Laboratory facilities for testing the quality of fishery products, The fishing industry in Ambon AFP, (2) Development Aspects, including Inventory of internal factors that give rise to strengths and weaknesses and external factors that can give rise to opportunities and threats.

\section{d. Data collection technique.}

Data collection technique used in this research are : (1) Made a questionnaire to explore and collect primary data in accordance with the objectives of the study, (2) Determine Respondents who were in accordance with the work and responsibilities of the population that 
had been determined, (3) Respondents' answers to questions on the questionnaire were data that was ready to be processed, (4) Secondary data collection as supporting data was obtained from the Ambon AFP.

\section{e. Data analysis}

The analytical tool used in this study was a descriptive analysis aimed at describing the phenomena that exist and interpreting the conditions or relationships that exist chronologically and also the SWOT Analysis (Putri et al., 2018), which was used to identify various factors systematically to formulate a company's strategy. The analysis was based on a logic that can maximize strengths and opportunities but simultaneously minimize weaknesses (Weaknesses) and threats (Threats). Thus, strategic planning (strategic planner) must analyze the factors of the company's strategy (strengths, weaknesses, opportunities, and threats) in the current conditions. In this analysis, two factors must be systematically identified, internal and external. Internal factors in this analysis are Strength (S) and Weakness (W), while external factors were Opportunity $(\mathrm{O})$ and Threat $(\mathrm{T})$.

\section{RESULT AND DISCUSSION}

The Ambon Archipelago Fisheries Port is located within the Ambon Bay region, precisely in Pandan Kasturi Hamlet, Batu Merah Village, Sirimau District, Ambon City, and Maluku Province a Geographical Location of $03^{\circ}-40^{\prime}-42^{\prime}$ 'South Latitude and 128 $-10^{\prime}-32^{\prime \prime}$ East Longitude. Ambon PPN has an area of $\pm 6 \mathrm{Ha}\left(60,000 \mathrm{~m}^{2}\right)$ consisting of the land area of $35,000 \mathrm{~m}^{2}(3.5 \mathrm{Ha})$ and the area of the pier (Port pond) $\pm 25,000 \mathrm{~m}^{2}(2.5 \mathrm{Ha})$.

The Ambon AFP began construction in the 1984/1985 fiscal year and was completed in 1996. At that time, the class was the Fish Landing Base (FLB) or Type D Port under the Maluku Provincial Fisheries Service. In 2000, FLB Ambon was upgraded to the Indonesian Archipelago Fisheries Port (Type B Harbor) with the status of a central Technical Implementation Unit (UPT) under the Directorate General of Capture Fisheries, Ministry of Maritime Affairs and Fisheries(Kementerian Kelautan dan Perikanan, 2012).

\section{a. Facilities and Infrastructure at Ambon AFP}

Existing facilities in Ambon AFP currently include (Yeni et al., 2017; Kementerian Kelautan dan Perikanan, 2012):

1. Main Facilities

In accordance with the Regulation of the Minister of Maritime Affairs and Fisheries number Regulation 08/Minister/2012 concerning Fishing Ports, Article 4 paragraph 5, the Principal Facilities that must exist at the Fishery Port (Kementerian Kelautan dan Perikanan, 2012) include as in the following Table :

Table 1. Ambon AFP Main Facilities

\begin{tabular}{llll}
\hline No & \multicolumn{1}{c}{ Basic Facilities } & Total & \multicolumn{1}{c}{ Volume } \\
\hline 1 & Port area & Unit & $35.609 \mathrm{~m}^{2}$ \\
& $\bullet$ Mainland & 1 Unit & $24.391 \mathrm{~m}^{2}$ \\
& $\bullet$ Sea / Harbor & 1 Unit & $(444,6 \times 8) \mathrm{m}^{2}$ \\
2 & Dock & 1 Unit & $(4-10) \times 6 \mathrm{~m}^{2}$ \\
3 & Trestle / Jetty & 8 Unit & $\left(6-100 \mathrm{~m}^{2}\right.$ \\
4 & Revetment & 1 Unit & 600 \\
5 & Complex Roads & 1 Unit & $3000 \mathrm{~m}^{2}$ \\
6 & Complex Fence & 1 Unit & $1.027 \mathrm{~m}^{2}$ \\
7 & Open Drainage & 1 Unit & $1.317 \mathrm{~m}^{2}$ \\
8 & Closed Drainage & 1 Unit & $110 \mathrm{~m}^{2}$ \\
9 & Groin & 345 Unit & $0,5 \times 0,5 \times 0,5 \mathrm{~m}^{2}$ \\
\hline
\end{tabular}


2. Functional Fasilities

Regulation of the Minister of Maritime Affairs and Fisheries number Regulation 08/Minister 2012 concerning Fishing Ports, article 4 paragraph 3, provides a limitation of functional facilities (Kementerian Kelautan dan Perikanan, 2012), in general, consisting of in the following table :

Table 2. Ambon AFP Functional Facilities

\begin{tabular}{|c|c|c|c|c|}
\hline No & \multicolumn{2}{|l|}{ Functional Facilities } & Total & Volume \\
\hline 1 & \multicolumn{2}{|l|}{ Fish Auction Building } & 1 Unit & $(25 \times 15) \mathrm{m}^{2}$ \\
\hline 2 & \multicolumn{4}{|l|}{ Water Installation } \\
\hline & - Aresian Well & & 1 Unit & \\
\hline & - $\quad$ Tank & & 2 Unit & \\
\hline 3 & \multicolumn{2}{|l|}{ Fuel tank and installation } & 1 Unit & $500 \mathrm{~m}^{3}$ \\
\hline 4 & \multicolumn{2}{|l|}{ Electricity and Installation } & 1 Unit & $82,5 \mathrm{KVa}$ \\
\hline 5 & \multicolumn{2}{|l|}{ Generator set } & 2 Unit & $18 \mathrm{Kva} \& 75 \mathrm{KVa}$ \\
\hline 6 & \multicolumn{2}{|l|}{ Assembly Hall } & 1 Unit & $500 \mathrm{~m}^{2}$ \\
\hline 7 & \multicolumn{2}{|l|}{ Administration Office } & 1 Unit & $1133 \mathrm{~m}^{2}$ \\
\hline 8 & \multicolumn{2}{|l|}{ One-stop office } & 1 Unit & $150 \mathrm{~m}^{2}$ \\
\hline 9 & \multicolumn{2}{|l|}{ Parking area } & 1 Unit & $1155,95 \mathrm{~m}^{2}$ \\
\hline 10 & \multicolumn{2}{|l|}{ Garage } & 1 Unit & $145 \mathrm{~m}^{2}$ \\
\hline 11 & \multicolumn{2}{|l|}{ House for Generator set } & 1 Unit & $125 \mathrm{~m}^{2}$ \\
\hline 12 & \multicolumn{2}{|l|}{ Navigation Lights } & 3 Unit & \\
\hline 13 & \multicolumn{2}{|l|}{ Ice factory } & 1 Unit & 10 Ton \\
\hline 14 & \multicolumn{2}{|l|}{ Reefer container } & 1 Unit & $20 \mathrm{Ft}$ (12 ton) \\
\hline 15 & \multicolumn{2}{|l|}{ Reefer containerBuilding } & & $20 \mathrm{Ft}$ (4 ton) \\
\hline 16 & \multicolumn{2}{|l|}{ Air Blast FreezerContainer } & 1 Unit & $325,50 \mathrm{~m}^{2}$ \\
\hline 17 & \multicolumn{2}{|l|}{ Cooperative building } & 1 Unit & $100 \mathrm{~m}^{2}$ \\
\hline 18 & \multicolumn{2}{|l|}{ Hydrant } & 1 Unit & \\
\hline 19 & \multicolumn{2}{|l|}{ Fire Safety } & 10 Unit & \\
\hline 20 & \multicolumn{2}{|l|}{ Speed boat } & 1 Unit & \\
\hline 21 & \multicolumn{2}{|l|}{ Forklift } & 1 Unit & 5 Ton \\
\hline 22 & \multicolumn{2}{|c|}{ Forklift Garage } & 1 Unit & \\
\hline 23 & \multicolumn{2}{|c|}{ Occupational Health and Safety } & 1 Unit & \\
\hline 24 & \multicolumn{4}{|c|}{ Telecommunication } \\
\hline & - Telephone & & 3 Unit & \\
\hline & - $\quad$ SSB Radio & & 2 Unit & \\
\hline & - Internet & & 1 Unit & \\
\hline
\end{tabular}

3. Supporting Facilities

Supporting Facilities function indirectly to support the smooth management of fishing ports. Minister of Maritime Affairs and Fisheries Regulation number Regulation08/Minister/2012 concerning Fishing Ports, Article 4 paragraph 4, provides a general limitation of supporting facilities (Yeni et al., 2017; Kementerian Kelautan dan Perikanan, 2012) consisting of Fishermen Meeting Centers, Mess Operators, Fishermen's Houses, Social and Public Facilities such as Worship, bath-wash-toilet, shops, and security posts. In Ambon AFP, the existence of supporting facilities in general consists of 5 facilities included in the function group as mentioned above, can be seen in the following table :

Table 3. Ambon AFP Supporting Facilities

\begin{tabular}{clrl}
\hline No & Supporting & Total & \multicolumn{1}{c}{ Volume } \\
\hline 1 & Official residence & 5 Unit & $1 \times 120 \mathrm{~m}^{2} ; 4 \times 36 \mathrm{~m}^{2}$ \\
2 & Guest House & 1 Unit & $120 \mathrm{~m}^{2}$ \\
3 & Security Post & 2 Unit & $2(4 \times 5) \mathrm{m}^{2}$ \\
4 & Science and & 1 Unit & 10 \\
5 & Public toilet & 1 Unit & $40 \mathrm{~m}^{2}$ \\
\hline
\end{tabular}


4. Operational Performance.

Since being established as a type B fishing port, Ambon AFP has experienced much progress in terms of its facilities and its performance in providing services where this can be seen at the operational level.

Fisheries port operations include services to fishing communities. The services provided by Ambon AFP to fishers in the form of services that support fishers operational activities such as fulfilling logistical needs for sailing supplies and issuance of sailing permits, catch landing activities, distribution, and marketing of catches and ship repair activities.

Table 4. Ambon AFP Main Performance Indicators 2013-2017

\begin{tabular}{|c|c|c|c|c|c|c|}
\hline No & Indicators & 2013 & 2014 & 2015 & 2016 & 2017 \\
\hline 1 & Ship Visits & 491 & 867 & 906 & 1.121 & 1.310 \\
\hline 2 & Fish Landing (ton) & 8.214 & 23.825 & 62.689 .452 & 72.014 .452 & 73.901 .742 \\
\hline 3 & $\begin{array}{l}\text { Number of } \\
\text { Fishermen \& } \\
\text { Manpower (people) }\end{array}$ & 7.439 & 9.180 & 9.518 & 9.613 & 6.450 \\
\hline 4 & $\begin{array}{l}\text { Clean water delivery } \\
\text { (tons) }\end{array}$ & 7.620 & 11.940 & 22.048 & 883 & 8164 \\
\hline 5 & $\begin{array}{l}\text { Fuel Distribution } \\
(\mathrm{Kl})\end{array}$ & 19.287 & 29.186 & 37.866 & 30.832 & 9.061 \\
\hline 6 & $\begin{array}{l}\text { Distribution of Ice } \\
\text { (tons) }\end{array}$ & 358 & 147 & 210.900 & 520.700 & 132.700 \\
\hline 7 & $\begin{array}{l}\text { Non-Tax Revenue } \\
\text { (Rp) }\end{array}$ & 365.083 .810 & 475.252 .618 & 518.130 .792 & 515.478 .750 & 673.898 .612 \\
\hline
\end{tabular}

\section{b. Analysis of Ambon AFP Conditions on Criteria for a OFP}

1. The First Criteria : Able to serve fishing vessels that conduct fisheries activities in Indonesian waters, the Indonesian Exclusive Economic Zone and the High Sea.

From the research result obtained data as in the following table :

Table 5. Catching Results Based On Catching Area

\begin{tabular}{|c|c|c|c|c|c|c|}
\hline \multirow{2}{*}{$\begin{array}{c}\text { Catching } \\
\text { Area }\end{array}$} & \multirow{2}{*}{ Total } & \multicolumn{5}{|c|}{ Years } \\
\hline & & 2013 & 2014 & 2015 & 2016 & 2017 \\
\hline Arafura Sea & 148.540 .625 & 46.479 .086 & 8.211 .000 & 21.924 .233 & 61.538 .987 & 69.842 .222 \\
\hline Maluku Sea & 18.985 & 0 & 0 & 0 & 625.965 & 1.353 .580 \\
\hline Banda Sea & 1.918 .393 & 13.240 & 3.500 & 1.901 .653 & 524.500 & 818.650 \\
\hline \multicolumn{2}{|c|}{ Total } & 46.492 .326 & 8.214 .500 & 23.825 .886 & 62.689 .452 & 72.014 .452 \\
\hline
\end{tabular}

From the results of the research conducted, it is knownthat the ships that landed their catches in Ambon AFP, mostly carried out fishing activities in the Territorial Region (Maluku Sea), EEZ (Arafura Sea) and International Waters (Banda Sea). So the Ambon AFP has fulfilled the first criteria of an Ocean Fishery Port (Yeni et al., 2017; Hutapea et al., 2018; Kementerian Kelautan dan Perikanan, 2012).

2. The Second Criteria : Have mooring facilities for fishing vessels measuring at least 60GT.

The Mooring facilities owned by Ambon AFP can be seen as in the following table :

Table 6. Ambon AFP Mooring Facilities

\begin{tabular}{clcc}
\hline No & \multicolumn{1}{c}{ Fasilities } & Total & Volume \\
\hline 1. & Dock & 1 unit & $(444,6 \times 8) \mathrm{m}^{2}$ \\
2. & Harbor Pond & & $24.391 \mathrm{~m}^{2}$ \\
3. & Trestle/Jetty & 8 unit & $(6-10) \times 6 \mathrm{~m}^{2}$ \\
4. & Revetment & 1 unit & $600 \mathrm{~m}^{2}$ \\
5. & Navigation & 3 unit & \\
\hline
\end{tabular}


Mooring facilities owned by Ambon AFP include Pier, Harbor Pool and Navigation lights, and all are in good condition and can be used for ships up to $200 \mathrm{GT}$, thus fulfilling the second requirement of an ocean fishery port(Yeni et al., 2017; Hutapea et al., 2018;Kementerian Kelautan dan Perikanan, 2012).

3. The Third Criteria : The length of the pier is at least $300 \mathrm{~m}$, with entry to the pool at least minus $3 \mathrm{~m}$.

The Pier in Ambon AFP is 444 meters long, with a depth of 3m pool. In 2012 there is also an increase of 60 meters of the pier's length to be 504 meters. Thus the Ambon AFPhas met criteria such as the Ocean Fishery Port (Yeni et al., 2017; Hutapea et al., 2018; Kementerian Kelautan dan Perikanan, 2012). The problem that may arise in the future is a necessity of sedimentation in the port pond. Further research is needed to remain in the ideal boundary so that incoming fishing vessels can carry out loading and unloading activities or maneuver and dock well.

4. The Fourth Criteria :Able to accommodate fishing vessels of at least 100 units or a total number of at least 6000GT.

From the research result obtained data as in the following table :

Table 7. Ship Visits Based On Ship Size

\begin{tabular}{|c|c|c|c|c|c|c|}
\hline & \multirow{2}{*}{ Ship Size } & \multicolumn{5}{|c|}{ Years } \\
\hline & & 2013 & 2014 & 2015 & 2016 & 2017 \\
\hline \multirow{9}{*}{ 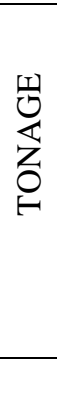 } & $<5$ & 2 & 0 & 0 & 0 & 0 \\
\hline & $5-10$ & 25 & 38 & 22 & 28 & 30 \\
\hline & $10-20$ & 45 & 122 & 67 & 102 & 7 \\
\hline & $20-30$ & 4 & 19 & 10 & 10 & 163 \\
\hline & $30-50$ & 73 & 136 & 105 & 157 & 8 \\
\hline & $50-100$ & 253 & 285 & 324 & 371 & 193 \\
\hline & $100-200$ & 32 & 122 & 142 & 199 & 424 \\
\hline & $>200$ & 57 & 145 & 236 & 254 & 485 \\
\hline & Total & 491 & 867 & 906 & 1121 & 1310 \\
\hline
\end{tabular}

Vessels that enter Ambon AFP on average have a large Gross Tonnage. Based on Ship Visit data, from 1310 ship visits, 424 are vessels with a size of 100-200 GT, and 485 ships measuring more than 200 GT in 2017. The data means that a total of 909 ships measuring more than 100GT. Even from direct observation, there were ships with a size of 2500 GT that were landing Fish. From this data, it is known that Ambon AFP has fulfilled the fourth criteria of an Ocean Fishery Port (Yeni et al., 2017; Hutapea et al., 2018; Kementerian Kelautan dan Perikanan, 2012).

5. The Fifth Criteria : Utilize and manage the land at least $20 \mathrm{Ha}$.

Ambon AFP has an area of $\pm 6 \mathrm{Ha}\left(60,000 \mathrm{~m}^{2}\right)$ consisting of land area/land area of $35,000 \mathrm{~m}^{2}(3.5 \mathrm{Ha})$ and the area of the pier (Port pond) $\pm 25,000 \mathrm{~m}^{2}(2.5 \mathrm{Ha})$. Ambon AFP also collaborates with the Maluku Provincial Maritime and Fisheries Service in Testing Fish Quality, where the testing Laboratory is outside the Ambon AFP area. Besides, Ambon AFP cooperates with Perikani (Public Corporation) to use workshops for fishing vessels that require workshop facilities. This workshop is also located outside the Ambon AFP area. From this data, it is known that Ambon AFP has fulfilled the fifth criteria of an Ocean Fishery Port (Yeni et al., 2017; Hutapea et al., 2018; Kementerian Kelautan dan Perikanan, 2012).

For the future, the Ambon AFP has also planned to expand the land to the west toward the Arumbae Market area. Concrete steps that have been carried out by the Ambon AFP in the context of land expansion include holding a meeting with the community around the Ambon 
AFP area, where the community has agreed to be relocated with several compensation agreements. This land expansion plan also has the support of the Maluku Governor and the Mayor of Ambon.

6. The Sixth Criteria : Fish landed were part of export purposes.

Fish marketing data based on marketing objectives for the past 5 (five) years can be seen in the following table :

Table 8. Fish Distribution Based On Marketing Areas

\begin{tabular}{cccccc}
\hline Marketing & \multicolumn{5}{c}{ Volume/Years $(\mathrm{Kg})$} \\
\cline { 2 - 6 } objective & 2013 & 2014 & 2015 & 2016 & 2017 \\
\hline Local & 3.423 .759 & 334.175 & 338.638 & 518.149 & 223.148 \\
Regional & 245.460 & 4.070 .202 & 3.576 .175 & 2.349 .988 & 2.450 .300 \\
Export & 2.756 .808 & 8.507 .532 & 54.615 .028 & 69.626 .811 & 71.589 .717 \\
\hline
\end{tabular}

Distribution and marketing activities of fisheryproducts by the fishing industry in Ambon AFP consist of 3 (three) marketing objectives, namely local, regional, and export. For local marketing, it only covers Ambon Island, while for inter-island/destination marketing, the areas include Kendari, Makassar, Benoa, Surabaya, and Jakarta. For the export market, there are 2 (two) commodities. Frozen shrimp commodities are marketed with destination countries of Japan, Hong Kong, Vietnam, and China, whereas frozen mixed fish commodities are marketed with destinations of Thailand, Japan, and South Korea.Thus the Ambon AFP has met the Sixth criteria of the Ocean Fishery Port (Yeni et al., 2017; Hutapea et al., 2018; Kementerian Kelautan dan Perikanan, 2012).

7. The Seventh Criteria :There are fish loading and unloading activities and marketing of fishery products on average 50 tons per day

The number of fish landed in Ambon AFP over the past 5 years can be seen in the following table:

Table 9. Amount of Fish Landed for 2013-2017

\begin{tabular}{ccc}
\hline No & Year & Amount of \\
\hline 1 & 2013 & $8,214,500$ \\
2 & 2014 & $23,825,886$ \\
3 & 2015 & $62,689,453$ \\
4 & 2016 & $72,014,452$ \\
5 & 2017 & $73,901,742$ \\
\hline
\end{tabular}

From data above can be seen that the Ambon AFP has fulfilled the seventh criteria of an Ocean Fishery Port (Yeni et al., 2017; Hutapea et al., 2018; Kementerian Kelautan dan Perikanan, 2012).

8. The Eight Criteria :There is a fish processing industry and other supporting industries.

In Ambon AFP, there are approximately 20 fishing industries until 2017 namely: Damarina Alam Bahari Inc., Tri Satria Samudera 01 Inc., Mitra Utama Maluku Inc., Harta Samudera 01 Inc., Pemantik Sumber Pratama Inc., Fa. Sanu, Mina Sejahtera Inc., C.V. Tuna Maluku, Fatma Kamah, CV. Wandry Jaya, CV. Hatukau Mandiri, Fisheries and Maritime Service, Sinar Abadi Cemerlang Inc., Harta Samudra 02 Inc., Tri Satria Samudra 02 Inc., Indomina Bangun Persada Inc., Makara Inc., SamuderaPratama Jaya Inc., Sinar Abadi Cemerlang 02 Inc., Jaring Mas Inc..

From data above can be seen that the Ambon AFP has fulfilled the eight criteria of an Ocean Fishery Port (Yeni et al., 2017; Hutapea et al., 2018; Kementerian Kelautan dan Perikanan, 2012). 


\section{c. SWOT Analysis}

1. Identification of Internal and External Factors

Based on the identification of the potential in Ambon AFP, several important factors were found that became the basis for determining the strategy to improve Ambon AFPclass, as follows:

Table 10. Ambon AFP External and Internal Factors

\begin{tabular}{ll}
\hline \multicolumn{1}{c}{ INTERNAL FACTORS } & \multicolumn{1}{c}{ EXTERNAL FACTORS } \\
\hline STRENGHT $(\mathrm{S})$ & OPPURTUNITY $(\mathrm{O})$ \\
A. Strategic role $\left(\mathrm{S}_{1}\right)$ & A. Strategic location $\left(\mathrm{O}_{1}\right)$ \\
B. Existing facilities $\left(\mathrm{S}_{2}\right)$ & B. Government Regulations and \\
C. Fish Resources $\left(\mathrm{S}_{3}\right)$ & \multicolumn{1}{c}{ Policies $\left(\mathrm{O}_{2}\right)$} \\
D. Fisheries Companies $\left(\mathrm{S}_{4}\right)$ & C. Quality of Catches $\left(\mathrm{O}_{3}\right)$ \\
E. Fish Landing Volume $\left(\mathrm{S}_{5}\right)$ & D. Educational Institutions $\left(\mathrm{O}_{4}\right)$ \\
F. Excellent service $\left(\mathrm{S}_{6}\right)$ & E. Investor Interest $\left(\mathrm{O}_{6}\right)$ \\
G. Fsihing Vessel Visit $\left(\mathrm{S}_{7}\right)$ & F. Development of Catches $\left(\mathrm{S}_{7}\right)$ \\
H. Export Volume $\left(\mathrm{S}_{8}\right)$ & G. Marketing $\left(\mathrm{O}_{8}\right)$ \\
I. Labor $\left(\mathrm{S}_{9}\right)$ & H. Minapolitan Program $\left(\mathrm{O}_{9}\right)$ \\
\hline WEAKNESS $(\mathrm{W})$ & THREAT $(\mathrm{T})$ \\
A. Limited land $\left(\mathrm{W}_{1}\right)$ & A. The function of Ambon PPN is still \\
B. Low Involvement Fishermen $\left(\mathrm{W}_{2}\right)$ & \multicolumn{1}{c}{ not optimal $\left(\mathrm{T}_{2}\right)$} \\
C. The fish auction has not been $\mathrm{used}$ & B. Ilegal Fishing $\left(\mathrm{T}_{4}\right)$ \\
$\left(\mathrm{W}_{3}\right)$ & C. The law enforcement has not been \\
& optimal $\left(\mathrm{T}_{5}\right)$ \\
& D. The nearest fishing port $\left(\mathrm{T}_{6}\right)$ \\
\hline
\end{tabular}

\section{Assessment of External and Internal Factors}

To determine the weight and rating of the elements contained in internal and external factors, namely by providing a list of questions to 20 key respondents who were considered to be able to provide an appropriate assessment. The 20 respondents were: 1 person from the Maluku Province Maritime and Fisheries Service, 1 person from the Ambon City Maritime and Fisheries Service, 3 people from staff in the Ambon AFP, 13 from the company in the Ambon AFP, and 2 people from the community around the Ambon AFP area. The assessment of the 20 respondents was then compared with the total answers of all elements so that the relative weighting results obtained as shown in the table below:

Table 11. Weight And Rating Against Internal Factors

\begin{tabular}{|c|c|c|c|c|}
\hline \multicolumn{5}{|c|}{ INTERNAL STRATEGY FACTORS } \\
\hline & STRENGHT & WEIGHT & RATING & SCORE \\
\hline 1. & Strategic Role & 0.0415636 & 4.2 & 0.174567 \\
\hline 2. & Existing Facilities & 0.0390896 & 3.95 & 0.1544038 \\
\hline 3. & Fish Resources & 0.0410688 & 4.15 & 0.1704354 \\
\hline 4. & Fishing Company & 0.0395844 & 4 & 0.1583375 \\
\hline 5 . & Fish Landing Volume & 0.0395844 & 4 & 0.1583375 \\
\hline 6. & Excellent Service & 0.0390896 & 3.95 & 0.1544038 \\
\hline 7. & Fishing Vessel Visit & 0.0410688 & 4.15 & 0.1704354 \\
\hline 8. & Export Volume & 0.0410688 & 4.15 & 0.1704354 \\
\hline 9. & Labor & 0.0336467 & 3.4 & 0.1143988 \\
\hline \multicolumn{2}{|r|}{ WEAKNESS } & WEIGHT & RATING & SCORE \\
\hline 1. & Limited Land & 0.0331519 & 3.35 & 0.1110589 \\
\hline 2. & Low Involvement of & 0.0301831 & 3.05 & 0.0920584 \\
\hline 3. & The fish auction has not been used. & 0.0336467 & 3.4 & 0.1143988 \\
\hline
\end{tabular}


Table 12. Weight And Rating of External Factors

\begin{tabular}{|c|c|c|c|c|}
\hline \multicolumn{5}{|c|}{ EXTERNAL STRATEGY FACTORS } \\
\hline & OPPORTUNITY & WEIGHT & RATING & SCORE \\
\hline 1. & Strategic Location & 0.0445324 & 4.5 & 0.2003958 \\
\hline 2. & Government Regulation and Policies & 0.0415636 & 4.2 & 0.174567 \\
\hline 3. & Quality of Catches & 0.0410688 & 4.15 & 0.1704354 \\
\hline 4. & Educational Institutions & 0.0420584 & 4.25 & 0.1787481 \\
\hline 5. & Investor Interest & 0.0390896 & 3.95 & 0.1544038 \\
\hline 6. & Development of Catches & 0.0381 & 3.85 & 0.1466848 \\
\hline 7. & Marketing & 0.0381 & 3.85 & 0.1466848 \\
\hline 8. & Minapolitan Program & 0.0445324 & 4.5 & 0.2003958 \\
\hline & THREAT & WEIGHT & RATING & SCORE \\
\hline 1. & The Function of Ambon AFP is not optimal & 0.0341415 & 3.45 & 0.1177882 \\
\hline 2. & Ilegal Fishing & 0.0301831 & 3.05 & 0.0920584 \\
\hline 3. & The law enforcement has not been optimal & 0.0321623 & 3.25 & 0.1045275 \\
\hline 4. & The nearest fishing port & 0.0306779 & 3.1 & 0.0951014 \\
\hline
\end{tabular}

3. The determination of Ambon AFP Class Improvement Strategy

At this stage, there are two steps that must be done, namely the determination of the coordinates and the determination of Quadrants.

- The Determination of Coordinate Points

To determine the coordinates, the formula was used as follows :

$$
\begin{aligned}
& =\left(\frac{\text { Score of Strenght }- \text { Score of Weakness }}{2} ; \frac{\text { Score of Opportunity - Score of Threat }}{2}\right) \\
& =\left(\frac{1.4257546-0.3175161}{2} ; \frac{1.3723157-0.5000247}{2}\right) \\
& =\left(\frac{1.1082385}{2} ; \frac{0.8722909}{2}\right) \\
& =(0.5541192 ; 0.4361455)
\end{aligned}
$$

- The Determination of Quadrants

From the results of determining the coordinates of the internal and external factors on the coordinates $(0.5541192 ; 0.4361455)$ and both have positive values then it is in quadrantone.

\section{Alternative Strategy for Ambon AFP Development}

The resulting strategy consists of several alternative strategies. To determine the priority of the strategy carried out, the total weighting that comes from the relationship between SWOT elements contained in an alternative strategy. The total weight of the scores will determine the priority sequence of alternative strategies needed to develop a strategic plan for improving the Ambon AFP Class to become the Ocean Fishery Port..

Table 13. Rank of Alternative Strategy for Improving Ambon AFP Class

\begin{tabular}{ccccc}
\hline No & SWOT unit & Linkages & Weight & Rank \\
\hline 1 & Strategy SO & $\mathrm{S}_{1}, \mathrm{~S}_{2}, \mathrm{~S}_{3}, \mathrm{~S}_{4}, \mathrm{~S}_{5}, \mathrm{~S}_{6}, \mathrm{~S}_{7}, \mathrm{~S}_{8}, \mathrm{~S}_{9}, \mathrm{O}_{1}, \mathrm{O}_{2}, \mathrm{O}_{3}, \mathrm{O}_{4}, \mathrm{O}_{5}, \mathrm{O}_{6}, \mathrm{O}_{7}, \mathrm{O}_{8}$ & 0.68481 & 1 \\
2 & Strategy ST & $\mathrm{S}_{1}, \mathrm{~S}_{2}, \mathrm{~S}_{3}, \mathrm{~S}_{4}, \mathrm{~S}_{5}, \mathrm{~S}_{6}, \mathrm{~S}_{7}, \mathrm{~S}_{8}, \mathrm{~S}_{9}, \mathrm{~T} 1, \mathrm{~T}_{2}, \mathrm{~T}_{3}, \mathrm{~T}_{4}$ & 0.513112 & 2 \\
3 & Strategy WO & $\mathrm{W}_{1}, \mathrm{~W}_{2}, \mathrm{~W}_{3}, \mathrm{O}_{1}, \mathrm{O}_{2}, \mathrm{O}_{3}, \mathrm{O}_{4}, \mathrm{O}_{5}, \mathrm{O}_{6}, \mathrm{O}_{7}, \mathrm{O}_{8}$, & 0.426027 & 3 \\
4 & Strategy WT & $\mathrm{W}_{1}, \mathrm{~W}_{2}, \mathrm{~W}_{3}, \mathrm{~T}_{1}, \mathrm{~T}_{2}, \mathrm{~T}_{3}, \mathrm{~T}_{4}$ & 0.25433 & 4 \\
\hline
\end{tabular}

\section{Formulation of Strategy}

The formulation of the Ambon AFP Class Improvement strategy using the SWOT matrix as an analytical tool can produce four possible strategies; namely, SO strategy, ST strategy, WO strategy, and WT strategy, by combining internal and external identification matrices. The 
analysis conducted is based on Rangkuti (2006), which is based on the logic of maximizing strengths and opportunities and simultaneously minimizing weaknesses (Weaknesses) and threats (Threats). This SWOT analysis is used as a guide (guideline) to determine the strategy to improve the class of Ambon AFP to an Ocean Fishery Port.

From the results of the analysis using the SWOT matrix, it was obtained linkages between internal and external factors. The linkage between internal and external factors resulted in 10 alternative strategies. The ten alternative strategies in question are as follows:

Table 14. Alternative Strategy for Improving Ambon AFP Class

\begin{tabular}{|c|c|c|}
\hline & STRENGHT (S) & WEAKNESS (W) \\
\hline IFAS & $\begin{array}{l}\text { 1. Strategic Role } \\
\text { 2. Existing facilities } \\
\text { 3. Fish Resources } \\
\text { 4. Fishing Company } \\
\text { 5. Landing Volume } \\
\text { 6. Excellent Services } \\
\text { 7. Fishing Vessel Visit } \\
\text { 8. Export Volume } \\
\text { 9. Labor }\end{array}$ & $\begin{array}{l}\text { 1. Limited land } \\
\text { 2. Low involvement of } \\
\text { fishermen } \\
\text { 3. Fish Auction place has not } \\
\text { been used }\end{array}$ \\
\hline $\begin{array}{l}\text { OPPORTUNITY (O) } \\
\text { OPOT }\end{array}$ & STRATEGY SO & STRATEGY WO \\
\hline $\begin{array}{l}\text { 1. Strategic location } \\
\text { 2. Government Regulations and } \\
\text { Policies } \\
\text { 3. Quality of Catches } \\
\text { 4. Educational Institutions } \\
\text { 5. Investor Interest } \\
\text { 6. Development of catches } \\
\text { 7. Marketing } \\
\text { 8. Minapolitan Program }\end{array}$ & $\begin{array}{l}\text { 1. Optimizing the services of } \\
\text { fishing vessels operating in the } \\
\text { Territorial, EEZ and International } \\
\text { waters } \\
\text { 2. Increased mooring capacity } \\
\text { 3. Optimization of the utilization } \\
\text { of the pier } \\
\text { 4. Product optimization for export } \\
\text { purposes }\end{array}$ & $\begin{array}{l}\text { 1. Increase in AFP land } \\
\text { 2. Development of an integrated } \\
\text { business enterprise business } \\
\text { model system }\end{array}$ \\
\hline THREAT (T) & STRATEGY ST & STRATEGY WT \\
\hline $\begin{array}{l}\text { 1. The function of Ambon AFP is } \\
\text { still not optimal } \\
\text { 2. Illegal Fishing } \\
\text { 3. The law enforcement has not been } \\
\text { optimal } \\
\text { 4. Nearest Fishing Port }\end{array}$ & $\begin{array}{l}\text { 1. Enhancing basic facilities, } \\
\text { functional facilities and supporting } \\
\text { facilities } \\
\text { 2. Increased surveillance in the Sea } \\
\text { of Illegal Fishing Activities }\end{array}$ & $\begin{array}{l}\text { 1. Development of quality } \\
\text { testing collaboration } \\
2 . \text { Increasing the capacity of } \\
\text { value-added oriented industries } \\
\text { 3. Development of cooperation } \\
\text { in the utilization of workshops } \\
\text { and slipways }\end{array}$ \\
\hline
\end{tabular}

\section{d. Strategic Recomendation}

Of the 10 Alternative Strategies obtained previously, the Strategy Recomendations that can be developed are as follows :

1. Optimization of Fishing Vessel Services operating in territorial territories, EEZ and international waters, the recomendations of development:

- Increase the socialization and promotion of Ambon AFP service capacity to fishing companies whose fleets operate in the service area.

- Develop facilities for Ambon AFP users for fishing vessels operating in the Territorial, EEZ, and international waters.

2. Increasing mooring capacity, the recomendations of development :

- Increase the number of vessels with a capacity of $30 \mathrm{GT}$ and above in utilizing the Mooring facility

- Increase the socialization and promotion of mooring service capacity owned by AFP Ambon.

3. Optimization of the utilization of the pier, the recomendations of development :

- Increase the number of fleets utilizing the pier owned by AFP Ambon.

- Increase the totality of pier services

4. Production Optimization for export market purposes, development recomendations :

- Increase the volume of production that is directed for export purposes

- Develop a marketing network of direct fishery products for export. 
5. Ambon AFP Land Development, the development recomendations :

- Prepare and socialize the academic concept of land development needs as a critical AFP Ambon need in improving services for fishing vessels.

- Establish intensive communication with the community and local government related to Ambon land development.

6. Development of Integrated Mina Business System models, the recomendations of development :

- Develop a model for developing a business system that accommodates fishing, processing, and distribution.

- Providing key facilities that support value-added oriented processing activities.

7. Enhancing the Basic Facilities, Functional Facilities, Supporting Facilities, and other facilities that support industrial activities, the recomendations of development :

- To raise funding facilities that are not yet optimal from the Government or the private sector.

- To raise funding for the development of functional facilities that are not optimal from the Government and the private sector.

- Mobilize Funding for the development of Support Facilities that have not been optimal, both from the Government and the private sector.

- Raise other development funds to support industrial activities in the Ambon AFP environment.

8. Increasing Oversight of the Sea of Illegal Fishing, the recomendations of development :

- Increase supervision of illegal fishing activities

- Increase funding for surveillance activities in the Sea of illegal fishing activities

- Increasing cooperation with related parties in overcoming the problem of illegal fishing

9. Development of Quality Testing Cooperation, the recomendations of development :

- Building a quality test laboratory in AFP Amboncarried out jointly between AFP Ambon and fisheries management institutions in Maluku Province.

- Developing quality testing activities jointly with the province to support the optimization of port functions in the context of quality testing.

- Increase the share of quality testing management with the provincial government.

10. Increasing the capacity of value-added oriented industries, the recomendations of development :

- Develop processing industries to increase economic added value in AFP Ambon, Ambon city, and Maluku Province.

- Creating a conducive investment atmosphere for investors who want to develop the processing industry in AFP Ambon, so it is not limited to handling activities.

\section{CONCLUSION}

Research on the Analysis of the Strategy for Improving the Class of the Ambon Archipelago Fisheries Port into an Ocean Fishery Port produces several conclusions :

1. Existing operations in Ambon AFP show increasing development from year to year, both in fish landing, fishing vessel visits, supply distribution, non-tax state revenue, and fishers and labour. The carrying capacity of the Ambon AFP, in general, is full and meets the criteria for the establishment of an Ocean Fishery Port

2. From the Ambon AFP Development Strategy's research results in improving the class to an Ocean Fisheries Port, ten strategies were produced.

\section{REFERENCES}

Bahasoan, H., Hakim, D. B., Nurmalina, R., \& Putri, E. I. K. (2020). JOURNAL OF TRADING, ECONOMICS AND Analysis of Growth Center and Hinterland Areas in Maluku Province Indonesia. 2(2009), 8-13. https://gnomepublications.org/ArticlePDFs/Trading/JTEB002.2-0001.pdf 
Hutapea, R. Y. ., Solihin, I., \& Nurani, T. W. (2018). PERAN PELABUHAN PERIKANAN SAMUDERA NIZAM ZACHMAN DALAM MENDUKUNG INDUSTRI TUNA (The Role of Nizam Zachman Oceanic Fishing Port to Support Tuna Industries). Marine Fisheries: Journal of Marine Fisheries Technology and Management, 8(2), 187. https://doi.org/10.29244/jmf.8.2.187-198

Kementerian Kelautan dan Perikanan. (2012). Peraturan Menteri Kelautan dan Perikanan RI Nomor PER.08/MEN/2012 Tentang Kepelabuhanan Perikanan. 1-20. http://jdih.kkp.go.id/peraturan/per-08-men-2012.pdf

Kim, D. J., \& Yeo, D. J. (2020). Estimation of drafts and metacentric heights of small fishing vessels according to loading conditions. International Journal of Naval Architecture and Ocean Engineering, 12, 199-212. https://doi.org/10.1016/j.ijnaoe.2019.11.001

Putri, A. S., Solihin, I., \& Wiyono, E. S. (2018). Strategi Optimalisasi Fungsi Pelabuhan Perikanan Dalam Pemasaran Hasil Tangkapan Di Ppp Lempasing. ALBACORE Jurnal Penelitian Perikanan Laut, 1(2), 171-183. https://doi.org/10.29244/core.1.2.171-183

Raissa, D. R., Setiawan, R. P., \& Rahmawati, D. (2014). Identification of Indicators Influencing Sustainability of Minapolitan Area in Lamongan Regency. Procedia - Social and Behavioral Sciences, 135, 167-171. https://doi.org/10.1016/j.sbspro.2014.07.342

Salaria, N. (2003). Process oriented information management in construction. International Journal of Transformation in Business Management, 1(6), 1-7. http://www.ijtbm.com/

Septiono, M. A., Roosmini, D., Salami, I. R. S., Ariesyadi, H. D., \& Lufiandi. (2016). Industrial Activities and Its Effects To River Water Quality (Case Study Citarum, Bengawan Solo and Brantas), an Evaluation for Java Island As an Economic Corridor in Master Plan of Acceleration and Expansion of Indonesia Economic Development (Mp3Ei) 2011. The 12th International Symposium on Southeast Asian Water Environment (SEAWE2016), November.

Soemarmi, A., \& Diamantina, A. (2019). Konsep Negara Kepulauan Dalam Upaya Perlindungan Wilayah Pengelolaan Perikanan Indonesia. Masalah-Masalah Hukum, 48(3), 241. https://doi.org/10.14710/mmh.48.3.2019.241-248

Yeni, E., Naufal, A., Studi, P., Sumberdaya, P., \& Perikanan, F. (2017). Identifikasi aktivitas pengembangan fasilitas pelabuhan perikanan pantai lampulo banda aceh. November, 355-363. 